University of South Florida

DIGITAL COMMONS

Digital Commons @ University of

@ UNIVERSITY OF SOUTH FLORIDA

South Florida

8-1996

\title{
Seasonal Modulation of the West Florida Continental Shelf \\ Circulation
}

Robert $\mathrm{H}$. Weisberg

University of South Florida, weisberg@marine.usf.edu

Bryan D. Black

University of South Florida

Huijun Yang

University of South Florida

Follow this and additional works at: https://digitalcommons.usf.edu/msc_facpub

\section{Scholar Commons Citation}

Weisberg, Robert H.; Black, Bryan D.; and Yang, Huijun, "Seasonal Modulation of the West Florida Continental Shelf Circulation" (1996). Marine Science Faculty Publications. 387.

https://digitalcommons.usf.edu/msc_facpub/387

This Article is brought to you for free and open access by the College of Marine Science at Digital Commons @ University of South Florida. It has been accepted for inclusion in Marine Science Faculty Publications by an authorized administrator of Digital Commons @ University of South Florida. For more information, please contact digitalcommons@usf.edu. 


\title{
Seasonal modulation of the west Florida continental shelf circulation
}

\author{
Robert H. Weisberg, Bryan D. Black, and Huijun Yang \\ Department of Marine Science, University of South Florida, St. Petersburg, Florida
}

\begin{abstract}
Velocity data from $28^{\circ} \mathrm{N}, 84^{\circ} \mathrm{W}$ on the west Florida continental shelf are presented. The data were sampled from October 1993 through January 1995 at $1 \mathrm{~m}$ intervals between $3 \mathrm{~m}$ and $42 \mathrm{~m}$ in a total water depth of $47 \mathrm{~m}$. Their monthly means suggest an annual cycle hypothesized to be driven by a seasonally varying shelf-wide baroclinic structure. Motions at semi-diurnal, diurnal and synoptic time scales are seasonally modulated, both by wind forcing and stratification that decouples fluid motions from the damping effects of bottom friction. These motions are presented in the form of progressive vector plots. With 16 months of data, probability density and distribution functions for along-shore and acrossshore particle displacements over specific time intervals are constructed. For daily intervals, particles are equally likely to travel approximately $5 \mathrm{~km}$ (depending upon confidence interval) in any direction. For monthly intervals, particles may travel a few hundred $\mathrm{km}$, primarily along-shore.
\end{abstract}

\section{Introduction}

The west Florida continental shelf is a broad, gently sloping region of width equal to that of the sub-areal state of Florida. Its isobaths generally parallel the coastline which at mid-shelf is oriented approximately along $333^{\circ} \mathrm{T}$, and the $100 \mathrm{~m}$ isobath is located some $150-200 \mathrm{~km}$ offshore. The circulation on the west Florida shelf is driven by tides, winds and buoyancy fluxes, and it is steered by the joint affects of the earth's rotation and topography. The circulation is also influenced by the Gulf of Mexico's Loop Current that enters through the Yucatan Straits and exits as the Gulf Stream through the Straits of Florida, sidling close to the west Florida shelf break at times during its Gulf of Mexico transit.

Recognizing that the circulation is an important contributor to the distribution of bio-geochemical material properties, a study was initiated in fall, 1993 for the purposes of improving upon the description of the shelf circulation and its seasonal and synoptic variability. This study builds upon earlier measurements such as Niiler (1976), Koblinsky (1981), Mitchum and Sturges (1982), Marmorino (1983) and Halper and Schroeder (1990) that were either of short duration or located relatively far offshore. As a precursor to a shelf-wide array of currents measurements, an RD Instruments $600 \mathrm{kHz}$ acoustic Doppler current profiler (ADCP) was deployed midshelf on the $47 \mathrm{~m}$ isobath, as shown in Figure 1. The ADCP (with $30^{\circ}$ transducer configuration) was surface moored in a downward-looking mode and it recorded hourly velocities (vector averaged over 500 samples, each 1 second apart) at $1 \mathrm{~m}$ intervals between depths of $3 \mathrm{~m}$ to $42 \mathrm{~m}$ from October 5, 1993 to January 26, 1995 (approximately 16 months). The present Copyright 1996 by the American Geophysical Union.

Paper number 96GL02184

0094-8534/96/96GL-02184\$05.00 letter briefly describes the seasonal modulation of the observed circulation features, and it proceeds as follows. We first describe the means for both the entire 16 month deployment and for each month. Progressive vectors by month are then developed for motions occurring at semidiurnal, diurnal and synoptic time scales as well as for motions inclusive of all time scales, and the seasonal modulation of these hypothesized particle displacements is given. Based upon the progressive vector analysis, a set of probability density and distribution functions for along-shore and acrossshore particle displacements over specific time intervals is then presented followed by a discussion and summary.

\section{Record-length and Monthly Means}

The record-length (16 months) means and standard deviations for the along-shore $\left(333^{\circ} \mathrm{T}\right)$ and the across-shore $\left(63^{\circ} \mathrm{T}\right)$ components of flow are shown as a function of depth in Figure 2. The means for both components are essentially zero at all depths and the standard deviations for either component are about $10 \mathrm{~cm} \mathrm{sec}^{-1}$, being only slightly larger near the surface. The implication is a rather sluggish, barotropic circulation on average. The monthly means, however, given as horizontal velocity vectors at $10,20,30$ and $40 \mathrm{~m}$ depths in Figure 3, present a much different picture, in which the circulation is large and seasonally reversing. The monthly mean vectors tend to be oriented along-shore with largest magnitudes (about $10 \mathrm{~cm} \mathrm{sec}^{-1}$ ) directed toward the southeast (northwest) in spring (late summer/early fall). During other months the means are of smaller magnitude. When the monthly means are largest; for example, 10/93, 4/94, 9/94, they also show a systematic decrease with depth in the alongshore component consistent with a thermal wind balance.

\section{Progressive Vector Diagrams}

A progressive vector approximation is adopted for estimating the particle excursions at $3 \mathrm{~m}$ depth based upon the Eulerian observations. Position time series in the east and north coordinate directions $[x(t), y(t)]$ were calculated according to: $d x / d t=u(t)$ and $d y / d t=v(t)$, where $(u, v)$ are the Eulerian velocity components in $(x, y)$. This was done by month for the semi-diurnal, diurnal and synoptic time scales after bandpass filtering the original hourly data set and for the original unfiltered hourly data set. The results are shown in Figure 4 for the months of January, April, July and October, 1994. The format in each set of panels is similar, the only difference being the spatial scale which increases with the time scale from semi-diurnal at the top to inclusive of all time scales at the bottom. At the semi-diurnal time scale, welldefined, eccentric ellipses are observed each month owing to primarily deterministic forcing provided by the $M_{2}$ and $S_{2}$ tidal constituents. These ellipses are oriented with semi-major axes in the across-shelf direction and their associated particle 


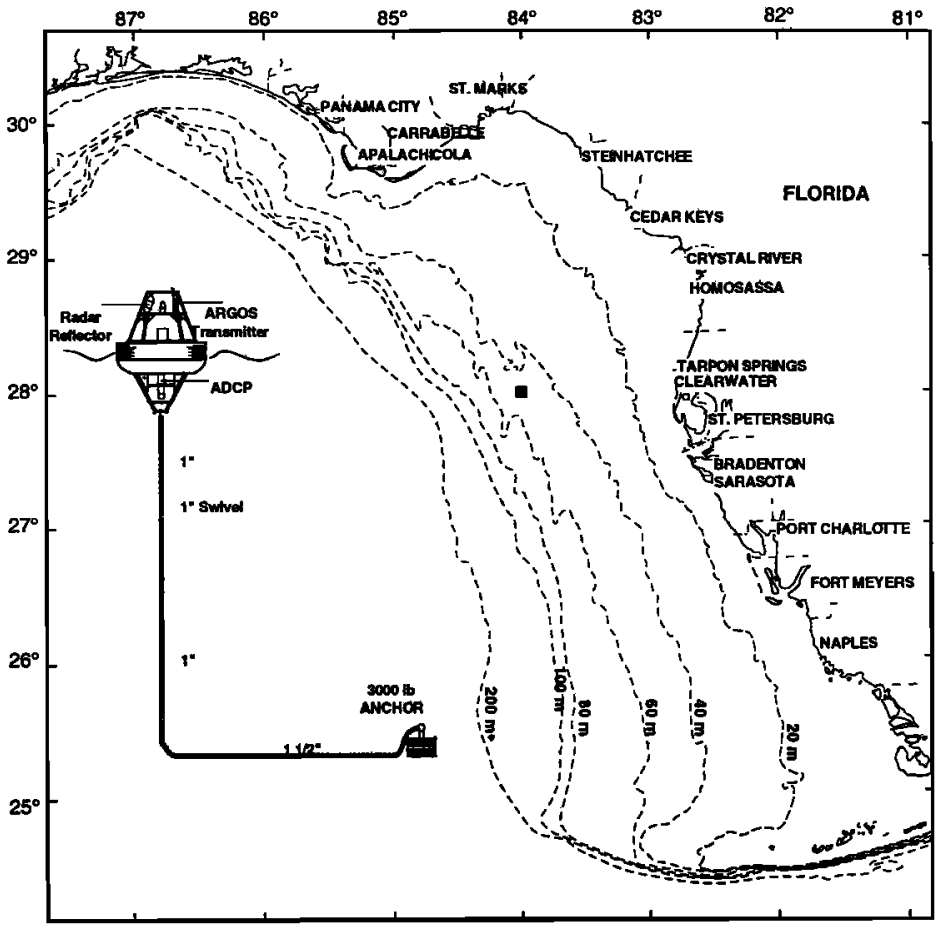

Figure 1. The west Florida continental shelf showing the mid-shelf ADCP mooring at $28^{\circ} \mathrm{N}, 84^{\circ} \mathrm{W}$ on the $47 \mathrm{~m}$ isobath.

excursions over a tidal cycle are about plus and minus $1 \mathrm{~km}$ in the across-shelf direction. The exception is in the summer months when stratification permits internal tides, adding a small random modulation about an otherwise deterministic, barotropic semi-diurnal tide. The diurnal time scale shows a much larger seasonal modulation. With the mooring at $28^{\circ} \mathrm{N}$ the inertial and diurnal time scales are very close to each other. During winter months the diumal ellipses are well-defined and forced primarily by the deterministic $O_{1}$ and $K_{1}$ tidal constituents, resulting in across-shelf oriented (but less eccentric) ellipses having particle displacements similar in magnitude as the semi-diumal tides. Once the water column stratifies, permitting internal waves and decoupling the inertial motions from the frictional affects of the bottom, the diumal ellipses become random, nearly circular and large, with particle displacements having $5 \mathrm{~km}$ radii in July. The diurnal time scale is therefore both tide and wind forced, but the wind forced response is largest when the wind (measured at a NOAA buoy located at $28.5^{\circ} \mathrm{N}, 84.5^{\circ} \mathrm{W}$ ) is smallest in summer, and conversely in winter, owing to the effects of stratification.

At synoptic time scales, the particle motions are primarily wind-forced. Since frontal systems are most pronounced in fall and winter, the synoptic time scale displacements are largest during those times. Due to the steering effects of topography, these displacements tend to align with the along-shore direction. Typical frontal passage in winter can therefore result in along-shore displacements of plus and minus $10 \mathrm{~km}$, as compared to less than half that amount in summer. Along with the semi-diurnal, diurnal and synoptic fluctuations, there are also the monthly varying mean flows (Figure 3). Thus, monthly particle displacements, inclusive of motions at all time scales, can be very large (the bottom panels of Figure 4), with the seasonally varying background circulation resulting in primarily along-shore displacements of $100-300 \mathrm{~km}$.
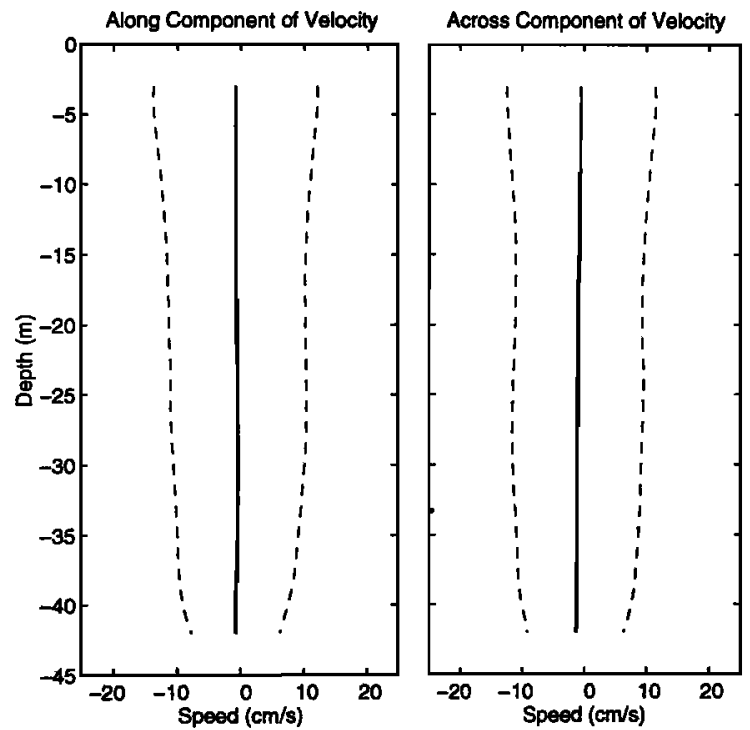

Figure 2. Vertical distributions of the record-length means and standard deviations for the along-shore and the acrossshore velocity components measured at $28^{\circ} \mathrm{N}, 84^{\circ} \mathrm{W}$.

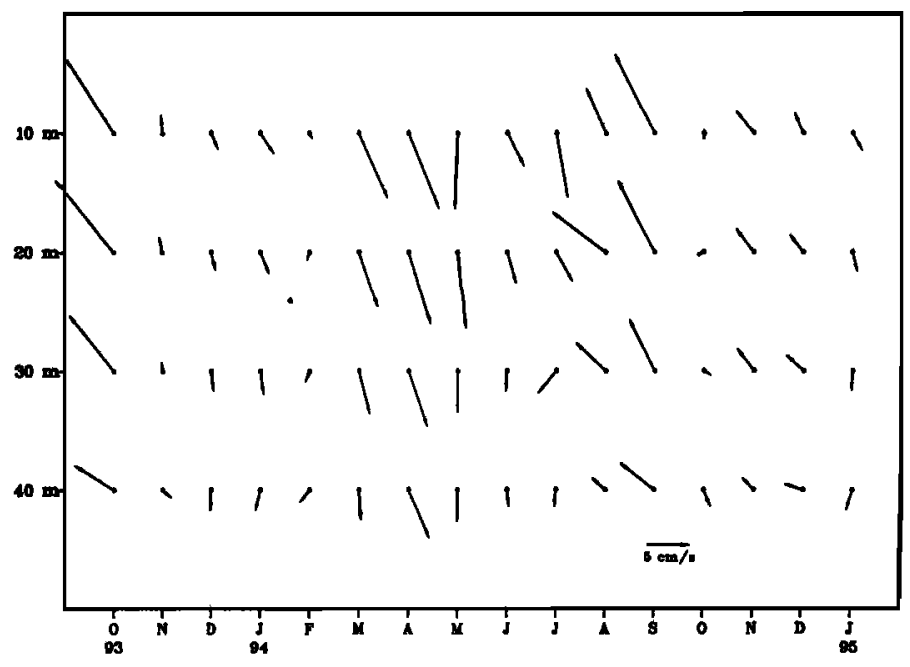

Figure 3. Monthly mean horizontal velocity vectors (north vertically up) at $10 \mathrm{~m}, 20 \mathrm{~m}, 30 \mathrm{~m}$ and $40 \mathrm{~m}$ depths at $28^{\circ} \mathrm{N}$, $84^{\circ} \mathrm{W}$. 

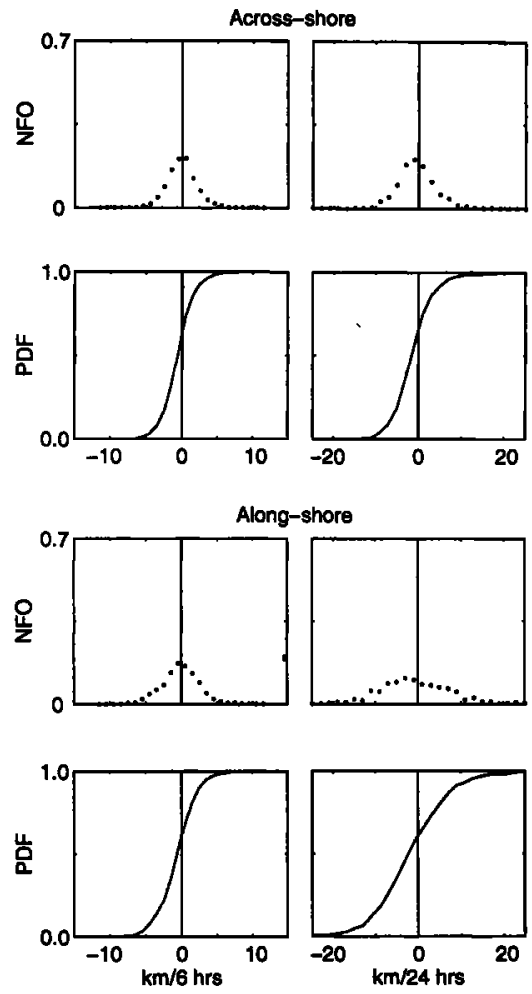

Figure 4. Monthly progressive vector diagrams (north vertically up) calculated from the Eulerian time series bandpass filtered about semi-diumal (0.0769-0.0841 $\mathrm{cph})$, diurnal (0.0370-0.0435 cph) and synoptic (0.00417-0.0125 cph) time scales and unfiltered to include all time scales. The data are from $3 \mathrm{~m}$ depth and the months of January, April, July and October, 1994 are representative of the seasonal modulation.

\section{Particle Displacement Probabilities}

The data allow for the construction of probability density and distribution functions for along-shore and across-shore particle displacements over specific time intervals. The intervals chosen are $6 \mathrm{hrs}$ (a typical time between satellite fixes for tracking drifting buoys) and 1 day (to average out tidal and inertial oscillations). The procedure consisted of calculating along-shore and across-shore displacements for each independent time interval (1912 at $6 \mathrm{hrs}$ and 478 at 1 day), forming normalized frequency of occurrence diagrams (probability density functions) and then integrating these to get probability distribution functions. The results are shown in Figure 5. At these intervals the along-shore and the acrossshore displacements are nearly Gaussian. Assuming (on average over the annual cycle) stationarity and homogeneity, Figure 5 may be used for making probabilistic statements regarding particle displacements at mid-shelf. For example, in the across-shelf direction, for a 1 day interval, there exists an equal probability that a particle will be displaced either onshore or off-shore and that the displacement magnitude with $90 \%$ confidence will be less than about $5 \mathrm{~km}$.

\section{Discussion and Summary}

Long term measurements of currents on the west Florida continental shelf reveal a seasonally varying background circulation and a seasonal modulation to the velocity fluctuations occurring in response to the shelf's primary forcing functions (i. e., the semi-diurnal and diurnal tides and the wind-forced motions at inertial and synoptic time scales). While the record-length mean flows in both the along-shore and across-shore directions are nil, the monthly means are relatively large at times $\left(10 \mathrm{~cm} \mathrm{sec}^{-1}\right)$, reversing direction from
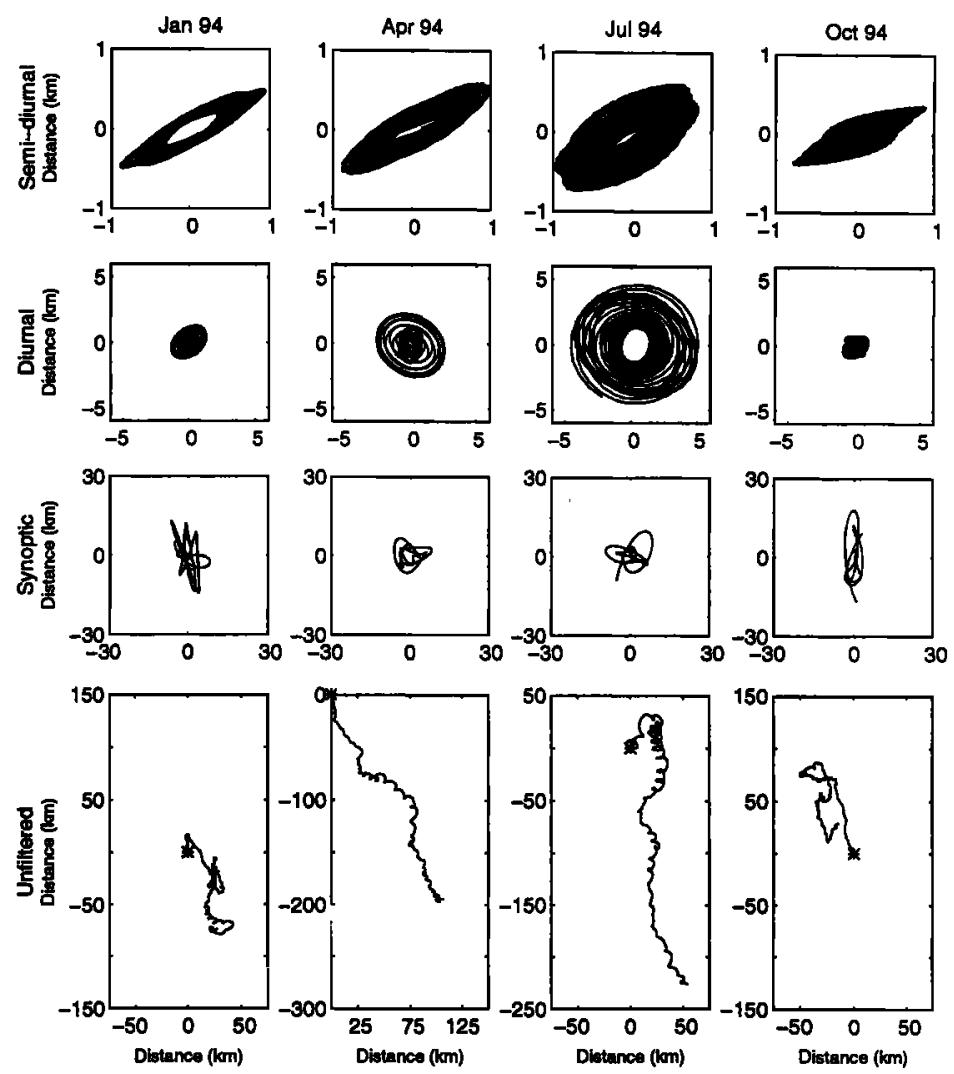

Figure 5. Probability density and distribution functions for particle displacements in the along-shore and the across-shore directions over time intervals of $6 \mathrm{hrs}$ and 1day inferred from the progressive vector analysis of 16 months of Eulerian velocity data observed mid-shelf at $3 \mathrm{~m}$ depth. 
primarily along-shore toward the northwest with maximum values in late summer/early fall to along-shore toward the southeast with maximum values in spring.

At the times of maximum monthly means, the vertical shear suggests a baroclinic origin via the thermal wind relationship. A simplistic way of thinking about this is to recognize that during winter (summer) months the waters at the shelf break are relatively warm (cold) compared with the waters on the shelf. From this one can hypothesize a reversal in the across-shore density gradient (and therefore the across-shore pressure gradient) consistent with a geostrophic reversal in the currents. This conceptual model appears to work in late summer/early fall when the near coastal waters are warmer and also fresher (the rainy season) than the waters farther offshore resulting in a northwestward along-shore geostrophic current. Indeed the seasonal maximum in sea level at the coast occurs at this time (e. g., Blaha and Sturges, 1981). The strongest southeastward directed currents occurring in spring, rather than winter, are more difficult to explain. Inspection of satellite AVHRR images shows a local SST minimum occurring between the mooring location and the coast (e. g. Vukovich, 1986) in spring as the shelf warms from south to north and offshore from the coast. This would effectively increase the acrossshore pressure gradient. Developing a better understanding of this seasonal baroclinic portion of the west Florida shelf circulation remains an important objective of our studies and it must be recognized that an improved, systematically collected hydrographic data set is required. It is also noted that these times series measurements help to explain the drift bottle retrievals under the "Hourglass Project" (Williams, 1977).

The findings that the semi-diurnal tidal currents may be described as well-defined, stable, barotropic ellipses, oriented across-shelf, are consistent with observations reported by Koblinsky (1981) and model predictions of Battisti and Clark (1982). Stratification during summer months, however, adds a small, random internal tide contribution.

In contrast to the semi-diumal tides, diumal period motions show a pronounced seasonal modulation due to the generation of random inertial oscillations that add to the deterministic, barotropic diurnal tides in summer months when the shelf is stratified. This contradicts the conclusion of Marmorino (1983) whose measurements were in winter when the inertial oscillations are critically damped by bottom friction.

The estimation of probability density and distribution functions for the bypothesized (using progressive vectors) along-shore and across-shore particle displacements show that particles, over time scales of $6 \mathrm{hrs}$ and 1 day, have nearly equal probability of flowing in any direction with daily displacements (depending upon confidence interval) being about $5 \mathrm{~km}$.

The complete record of currents reported herein along with the ancillary wind, sea level and temperature data are available in Weisberg et al. (1996). Future correspondences will include data from a recently recovered trans-shelf array of instruments.
Acknowledgments. Support was provided as part of the west central Florida coastal erosion study by a cooperative igreement between the USGS (Center for Coastal Geology, St Petersburg, FL.) and the University of South Florida, with equipment matching from the USF Division of Sponsored Research, and with additional support from the Florida DEP, FMRI, St. Petersburg, FL. We thank the Florida Institute of Oceanography, the USGS and the respective crews of the $R V$ Suncoaster, RV Bellows and $R V$ Gilbert for ship support. R. Cole and J. Donovan assisted with the field work and data analysis.

\section{References}

Battisti, D. S., and A. J. Clarke, Estimation of nearshore tidal currents on non-smooth continental shelves, J. Geophysical Res., 87, 7873-7878, 1982.

Blaha, J., and W. Sturges, Evidence for wind-forced circulation in the Gulf of Mexico, J. Marine Res., 39, 711-733, 1981.

Halper, F. B., and W. W. Schroeder, The response of shelf waters to the passage of tropical cyclones- observations from the Gulf of Mexico, Continental Shelf Res., 10, 777-793, 1990.

Koblinsky, C. J., The $\mathrm{M}_{2}$ tide of the west Florida shelf, Deep Sea Res., 28A, 1517-1532, 1981.

Marmotino, G. O., Variability of current, temperature, and bottom pressure across the west Florida shelf, winter 1981-1982, J. Geophysical Res., 88 4439-4457, 1983.

Mitchum, G. T., and W. Sturges, Wind-driven currents on the west Florida shelf, J. Phys. Oceanogr., 12, 1310-1317, 1982.

Niiler, P. P., Observations of low-frequency currents on the west Florida continental shelf, Mem. Soc. Roy. Sciences de Liege, 6, 331-359, 1976.

Vukovich, F. M., Aspects of behavior of cold perturbations in the eastern Gulf of Mexico: a case study, J. Phys. Oceanogr., 16, 176$188,1986$.

Weisberg, R. H., B. D. Black, J. C. Donovan and R. D. Cole, The westcentral Florida shelf hydrography and circulation study: a report on data collected using a surface moored acoustic Doppler current profiler, 129 pp.,Department of Marine Science, University of South Florida, St. Petersburg, FL, 1996.

Williams, J., W. F. Grey, E. B. Murphy, and J. J. Crane, Memoirs of the Hourglass Cruises, Volume 4 Part 3, Florida Department of Natural Resources, 133pp., 1977.

B. D. Black, R H. Weisberg, H. Yang, Department of Marine Science, University of South Florida, 1407 th Avenue South, St. Petersburg, FL 33701. (e-mail: black@ ocg6.marine.usf.edu; weisberg@ocg6.marine.usf.edu; yang @ocg6.marine.usf.edu)

(Received March 28, 1996; revised June 18, 1996; accepted June 24,1996 .) 